\title{
Bringing Back Kasada Ceremony Identity in The Middle of State Religious Penetration at Tengger Community
}

\author{
N. Hadi \\ Department of Sociology, Faculty of Social Science \\ Universitas Negeri Malang \\ geometrimolekul@yahoo.co.id
}

\begin{abstract}
Kasada ceremony is an important tradition about how Tengger community interacts with natural mountain environment and social interactions among them. Beside provide an identity and protection for commonality and togetherness preservation, this ceremony also maintain Tengger culture's existence. The aim of this study: (1) to describe Kasada ceremony tradition background as a form of ecological adaptation, also as a form of local knowledge and life skills education in their youth; (2) to describe Kasada ceremony tradition implementation with ethnographic background; (3) to describe and analyze the effect of state religion penetration in Tengger with Kasada ceremony tradition existence. This research method is a qualitative ethnography of Spradley models with exploratory research. The result showed: (1) Kasada ceremony background related to ecological adaptation, local knowledge and life skills education in youth; (2) Kasada ceremony is held once a year, needs various instruments and rituals, with an ethnographic background as mountain communities; (3) state religion penetration to Tengger has significant influence on Kasada ceremony existence. The implication of this study is Kasada ceremony must be protected from the state religious leaders' ambitions with restoring the identity of this ceremony in natural form.
\end{abstract}

Keywords-Identity;Kasada Ceremony; State Religious Penetration; Tengger Community

\section{INTRODUCTION}

Study on Tengger community post-independence has been done by Hefner, especially with a focus on the political economy aspect, which raises an important funding problem about egalitarianism of Tengger community into farm life ${ }^{1}$. An ethnic group is informal interest groups whose members are distinct from the members of other ethnic groups within the larger society because they share a kinship, religious and linguistic ties ${ }^{2}$. The assessment of religious life tolerance in Tengger, or the study of traits Tengger ethnic and the relationship with other ethnics in East Java has been done ${ }^{3}$. However, about Kasada ceremony tradition in particular has not been peeled frequently. The ceremony is related to character and life skills education that is another form of local wisdom Tengger community with all its uniqueness.

Religion is the substance of culture and culture is the form of religion ${ }^{4}$. Religion is not just a set of beliefs and rituals, but also an ethical code of conduct providing guidance for the constituents of the society. It teaches both the old and young on what is good for society and positive contribution for the advancement and preservation of the society ${ }^{5}$.Found an interesting fact that the Tengger community has embraced some state religion (i.e., Islam, Hindu, Buddhist and Christian). Tengger community in the villages of Pasuruan and Probolinggo district predominantly has religion, Hindu, in Lumajang district (Ranupani) has religion, Muslim, Hindu and Christian, while in the Malang district (Ngadas) have religion Buddhist, Muslim and Hindu. In some Tengger villages there is also still a religious follower of the original Budo (not Islam). The mention of Budoterm is to show the resistance to Islam, which is considered the fiercer hostile to their faith. The presence of these religions has an impact on the existence and continuity of Kasada ceremony. The followers of that religion still practice various Tengger traditional rituals, such as EntasEntas, Unan-Unan, Wologoro, and many monthly rituals, such as Kasa, Karo, Kapat, Kapitu, Kasodo, and others. However, there are some parts of that religion followers began to leave some big ceremony, such as Kasada and Karo $^{6}$.

A very prominent feature of the Tengger community in carrying out social activities and customs is the attitude of togetherness that is based on the feeling of harmony and peace. Various sacred ceremonies are always conducted in a spirit of togetherness. Especially in the implementation of Kasada ceremony, they run with full sincerity, joy, mutual cooperation, sacrifice, and a wide range of attitudes and behaviors that indicate an altitude of dignity as social beings. It shows that they run Java ethics ${ }^{7}$. The ceremony was conducted by the whole community, from elders, to children. Likewise, men and women are totally involved in its implementation. Kasada ceremony is believed as the remains of ancestors, in 
which there are many important and useful values to fuse with of daily social life aspects, in particular intertwine with their original religion 6 .

The state is a human community that successfully claims the monopoly of the legitimate use of physical force within a given region ${ }^{8}$. A post PKI coup in 1965, the New Order regime tried to homogenize not only Tengger community, but also most of the other Indonesian ethnic groups ${ }^{9}$. Central to its policy was to categorize people into just five state religious groups (Hinduism, Buddhism, Christianity, Islam) ${ }^{10}$. There were massif efforts from community outside Tengger to penetrate the state religion into Tengger community that was deemed "not" religious. It resulted this communities which already have Budo religious forced doing religious conversion. The phenomenon caused syncretism between Budo indigenous religion with any state religion and its all consequences ${ }^{6}$. This condition for a few things needs to get attention, associated with changes in traditional rituals mountain community with all local wisdom in it.

\section{MethodOLOGY}

The method used is a qualitative ethnographic approach with Spradley model groove gradually, which include the establishment of research subjects or informants, interview, ethnographic notes, descriptive question, interview, analysis, domain analysis, structural question, taxonomic analysis, contrast question, component analysis, and cultural theme findings ${ }^{11}$.This research explored the phenomenon deeply with limited theoretical support to raise completely new theoretical approach. The data collection process was done by observation and in-depth interviews, study and documentation about the beginning penetration and development of state religion in Tengger. Data was analyzed with Spradley model and an interaction analysis model that was developed by Miles and Huberman, which includes data reduction, data presentation, and conclusions drawing ${ }^{11,12}$.

Research subjects or informants are formal and informal leaders in Tengger (i.e.,Shaman, Wong Sepuh, Pak Legen, village chief) and some people, which were selected based on purposive sampling. Generally their characteristics are seen closed to newcomers, but among themselves they trust and help each other. They will be silent and wait, but they will be very open when they already know and trust us. It takes a long time to understand the real problem naturally, through some triangulation techniques.

\section{RESULT AND DISCUSSION}

\section{A. Kasada Ceremony Background}

Kasada ceremony has been done for a very long time. Tengger community is known as the descendant of Majapahit Kingdom and having Hindu religion ${ }^{9}$. Because of Islam followers attack from Demak Islamic kingdom which newly established, they run away from their original place around Mojokerto, East Java, to go to the east. Tengger community is some of the escapees which travel through Panarukan and Malang town. They colonize at Bromo and Semeru Mount slopes. In the course of time they developed their own calendar system based on month trip. Just like Java community in general, they developed a calendar system within one year consists of 12 months and once in every five years that month will be back one month, which be conducted by Unan-Unan ceremony 6 .

The biggest ceremony in Tengger social life is Karo ceremony (at $2^{\text {nd }}$ month) and Kasada ceremony (at $12^{\text {th }}$ month). Especially for Kasada ceremony, it involves various community aspects of life in an integrated manner. Their legend is about universe formation with a focus on Bromo and Semeru Mount, and also their origin as mountain community, such as mentioned in sacred story: Roro Anteng and Joko Seger ${ }^{9}$. Kasada ceremony is part of sacred story series, about the loss of their youngest child in the Mount Bromo crater. Their ancestor memorial performed by reading the legend of their origins at Kasada ceremony culmination, and throwing offerings into Mount Bromo crater. It was done for generations as a moral education to their youth ${ }^{6}$.

The Kasada ceremony background was associated with ceremonies for maintaining their community integrity. Kasada ceremony also has socioeconomic proximity to the mountain community. Kasada ceremony is associated with ecological adaptation, local knowledge and life skills education for the younger generation. The purpose of the ceremony is to remain grounded in the values of ancestral cultural traditions, by doing historical continuity and social integration ${ }^{3}$.

\section{B. Kasada Ceremony Implementation}

There are several activities by Tengger people to perform Kasada ceremony, which is conducted annually by the entire population of all villages in Tengger. Philosophically, the main purpose of this ceremony is to remain grounded and always remember the values of cultural tradition ancestor (by remembering and applying back of their collective memory as descendants of Mount Lord/Bromo), charitable and generous (by throwing ritual offerings), and important efforts to doing the historical continuity and social integration (held in conjunction with Dhiksa Widi exam ceremonies and the inauguration of the new Shaman) were carried out totally. Kasada ceremony has formed the spirit of togetherness. The fading spirit in the course of time will always be revitalized through the implementation of a ceremony that is always repeated every year. The values of compassion, harmony and peace are the hope and desired goal of Tengger community ${ }^{6}$.

Trips made by each family when departing larung (throwing ritual offerings into the crater), starting with preparing the offerings that will be floated and food that will be consumed in the course. The owner of offerings 
gives prayer at the house, after that with all family members they go to the crater. On the way there is a stop called Watu Shaman, where the offerings are given a mantra by the Shaman, some food are opened to be eaten with family members and some are given to the Shaman and his aides. The journey continues towards Poten Temple for again offerings brought are treated with charms by the Shaman who has the duty at the Temple. The end of the individually procession ceremony is performed by incorporating offerings into the crater of Mount Bromo. The offerings will be contested by some people who have been ready for the slopes of the crater ${ }^{13}$.

The peak of Kasada ceremony conducted on the 14th night 15th Kasada months (the twelfth month of Tengger calendar), with throwing their crops and livestock. Every person from each family had thrown ritual offerings in the days ahead Kasada. At the peak of event the most things that was thrown is Ongkek (offerings of the earth that shaped like animals). Tengger villages are totaling about 30 villages, which is each of them make a Ongkek, except village where there are citizens who died in Kasada month. Along with the peak Kasada ceremony there is also held the Dhiksa Widi ceremony (exam and at the same time inauguration of new Shaman). Unless leaders of Tengger Shaman, each Tengger village has Shaman, and Wong Sepuh and Pak Legen (helper Shaman) are appointed for life. If in a village there is a Shaman who died, then in that year Kasada ceremony from villages concerned, there will be Shaman candidates who will follow Dhiksa Widi ${ }^{6}$.

\section{Impact of State Religion Penetration To Kasada Ceremony}

\section{1) State Religion Penetration and Religion Conversion in Tengger}

During a very long time, Tengger people were isolated physically and culturally from the great tradition of Majapahit, have developed a unique cultural tradition, such as holding tight Wa-Lima lesson that consists of Waras (sound of body and mind), Wareg (satiety), Wastra (clothing), Wismo (home), and Wasis (ability). There was also developed the high values concerning the Seven Elements of Love (Welas Asih Pepitu), consisting of loving on Hong Pokulunthe Great, Mother Earth (ground), the elderly, physically and mentally, fellow beings, pets and the useful plants. Tengger people also recognize various restrictions contained in Tujuh Wewaler lesson, include a ban for being in Sadranan place (cemetery) and Punden (worship place under big tree); entering sanggar pamujan (holy place for Budo followers) without Shaman permission; saying dirty and rough, especially around Mount Bromo potent; moving the stones bounds yard or limit agricultural land; holding a puppet show (as it is believed Tengger as the place of the Gods); breaking pagarayu (love affairs); and doing Mo-Limo ${ }^{6}$.
Manners lessons which they have virtually complete. With variety of that customs Tengger people can live in harmony and peace for centuries. At isolated place for a long time they developed Budo as local religious beliefs, nuanced Animism. With that, local religion they survive for a long time. After going through a political tragedy G.30.S/PKI, everything changed. Some state religion from outside Tengger did penetration, so many Tengger people perform religious conversion of $B u d o$, into a state religion. In some places like Pasuruan and Probolinggo it was happened dramatic and massive, but in some other places like Malang and Lumajang happened gradually ${ }^{6}$.

People in some villages in Pasuruan and Lumajang, do conversion into the Hindu religion, according to the motion of Tengger leaders, who think historically that they are descendants of Majapahit Hindu adherents; Tengger community in villages on Lumajang converts into Christianity, Hinduism and Islam; while the teenager community in the villages on Malang has entered into Buddhism, Islam and Hinduism. Especially, penetration of Islam into Malang has entered heavily, even there is a village where is one hundred percent of the population was Muslim ${ }^{8}$. What a pity that inadvertent in does syi'ar Islam has led various religious Tengger symbols that we're distantly related to preservation of the natural environment being vanish. There are many large trees that have been felled because it is considered as a place of idols and make people commit shirk. This condition is even more alarming when it was realized that the large trees on sloping land as in Tengger is a catchment and water sources. Now the ecological problems arise when large trees have been felled ${ }^{6}$.

Problems about the entering of Buddhism into Tengger through Malang contain uniqueness. Terminology Budo in Tengger community which is a form of resistance to Islam, has been justified by the head panel of Buddhism in Malang to integrate Tengger religion to Buddhism, although in fact historically and based on belief systems and rites that performed is not the same. The similarity of names cause Budo followers is considered part of Buddhists by inviting and facilitating them in various celebrations held Buddhists, particularly in the implementation of Waisyak ceremony. Similarly, Buddhists have followed Tengger people praying in sanggar pamujan. That sanggarpamujan has turned into a Buddhist monastery now ${ }^{6}$.

\section{2) State Religion Penetration and Religious Conversion in Tengger}

After G.30.S/PKI event there were massive arrests of the Tengger people who were considered not to have a religion and a "just" wing beliefs. The horror happened forced Tengger community leaders did religious conversion, some of the Hindu, and some expressed religious Budo. The use of Budo terminology (not Buddha) is a resistance to Islam, which in the event of 
post-coup it became more interested in rooting out those who are considered "no religion". In the New Order several places of Hindus, Buddhists, Muslims and Christians worship also have much adorn the Tengger with all its consequences ${ }^{6}$.

The entering of some state religion has a diverse impact of the Kasada ceremony. Christians followers in Ranupan ivillage are not willing to undergo the ceremony, likewise some Islam followers in Ngadas village (Malang). Buddhists still run Kasada ceremony, but now they put more emphasis on Tengger community to have a certain place for Waisyak ceremony that they know recently to get more of their attention and respect. Tengger community seems to follow that advice. Especially many Tengger young men and women are given scholarship to be educated by Buddhist leaders in Surabaya, and later be returned to the Tengger for Buddhism developing ${ }^{6}$. An Even Budo holy place which was Sanggar Pamujan just before, has turned into a Buddhist monastery now.

In contrast, Hindu Tengger seems to have a different strategy in facing Tengger traditional ceremonies, especially Kasada. A strategy that they run is by entering heart lessons of Tengger. Budo traditional religion has completely changed. They established some temple in new places, even some of them are on the way up towards Mount Bromo trap, and now there is a temple which is considered as a central and most sacred place, called Pura Poten (Central Temple) ${ }^{9}$. On past trips to pull over offerings at Kasada peak was done by forming procession that starts from Cemoro Lawang Hamlet, Ngadisari Village, going down sea of sand and then going up to the crater of Mount Bromo. Now, almost all activities related to Kasada ceremony always begin and concentrate on Pura Poten. Even the exams and graduation ceremony of new Shaman are always held in this temple. In those who lied will easily declare that Kasada ceremony is a ceremony of Hindu, but not substantially so.

Everyone has freedom to choose his religion ${ }^{14}$. Tengger community has right to implement their religion lessons, include if they want to have religion converted. It is also related to the right to education, knowledge and following rapid science and technology progress during their limited geographical situation. Likewise, as citizens they properly deserve protection, security and prosperity from country in obtaining and retaining their rights as the local community. These include the right to maintain their identity as custom peoples with their original religion Budo and Kasada ceremony as part of their religion that nuance Animism mountains.

Prohibit the spread of religions States in Tengger is impossible, but allowing them to enter by destroying and replacing noble traditions must be resisted. Especially there should be East Java Province government policy for the leaders of religious State to respect each other in Tengger, by providing the widest opportunities to Tengger community about making a wise choice, in accordance with their ecological and sociological condition. Kasada ceremony is full of local genius and wisdom for the survival of the community and preserving togetherness spirit of Tengger community. Their identity as mountain community that concerned about the environment should be restored, by keeping the existence and continuity of ceremony.

The existence of Tengger people should be protected from the possibility of imposition from interests outside Tengger that not understand their local wisdom, and only concerned ego to impose their will in Tengger. Durkheim interesting note speech:

"Humans depend on religion, not only in charge of their knowledge, but also in the form of a place where the knowledge can be extracted. Deep in our judgment, there are fundamental concepts that dominate our entire intellectual life. Concepts of time, space, number, cause, substance and personality directly relate to the most universal properties of every creature" 15 .

That is highly relevant context with Budo religion on Tengger people. As an open society, Tengger community has rights to access information, included absorbing culture and religion from the outside should be supported. But their desire to maintain a tradition that brings benefit for their life exists in a unique space should be supported and protected.

The strength of Asian countries is the growth witnessed in foreign exchange reserve ${ }^{16}$. Although modern society is shared with pluralistic culture, however, important differences should always be an integral element of cultural development ${ }^{17}$. It probably will not be back as the time when the Kasadaceremony was initially conducted by the ancestral Tengger community, but do not make Tengger as a struggle arena for hegemony between different religions, State, with resulted that disunity and discord among the followers of religions state from the outside brought in to Tengger. The community living options to have a past history of identity must be respected, as well as their desire to absorb modernity should get high appreciation. All followers of religions state in Tengger should respect their native traditions, not to force followers, which are also Tengger people, to leave custom ceremonies, especially Kasada. The ceremony must be protected from: (1) followers of religions state that manipulate Budo traditional religious dogma; (2) prohibition from religious State leaders to Tengger people who perform this ceremony diligently; (3) activities of religious State leaders who perform removal and replacement Tengger holy sites with new buildings that damage the identity of Tengger. Maybe it is the time for Kasada traditional ceremony, along with all tools and accessories in which full of local knowledge and genius to be submitted to UNESCO as a world cultural heritage. 


\section{CONCLUSIONS}

The Kasada ceremony background was associated with efforts to maintain the integrity of Tengger community and related to ecological adaptation, local knowledge and life skills education in their youth. Kasada ceremony is held once a year, needs various instruments and rituals, with an ethnographic background as mountain communities. There are several activities conducted by Tengger people in Kasada ceremony, started by preparing offerings that will be floated and food that will be consumed in the course, melarung trip and asking the blessing from Shaman, then continued with throwing offering into the crater. At the peak of the event, Ongkek is floated and at the same time DhiksaWidi takes place. State religion penetration to Tengger has significant influence on Kasada ceremony existence. Some state religions asked the followers to leave Kasada ceremony and others changed the ceremony tradition by adapting to state religion teachings. The implication of this study is Kasada ceremony must be protected from the state religious leaders' ambitions with restoring the identity of this ceremony in natural form.

\section{REFERENCES}

[1] Hefner RW, "The Political Economy of Mountain Java An Interpretive History,"Barkeley and Los Angeles, California: University of California Press, 1990, pp.17-30.

[2] Agbalajobi DT and Akinlabi AA. "Ethnic Plurality and Democratic Process in Nigeria (1999-2011)," Developing Country Studies, 2015; 5(19): 104-6.

[3] Sutarto A, "Orang Tengger dan Tradisi Bekti Marang Guru Papat" in Pemetaan Kebudaayaan di Propinsi Jawa Timur, Sebuah Upaya Pencarian Nilai-Nilai Positif, A. Sutarto and S.Y. Sudikan, Eds. Surabaya: Biro Mental Spiritual Pemerintah Provinsi Jawa Timur Bekerja sama dengan Kompyawisda Jatim-Jember, 2008, pp.117-30.

[4] Chidi IL, Rose U, Uche A, "Utilization of Religious Education for Effective Inculturation of the Gospel," Journal of Philosophy, Culture and Religion, 2015; 12: 37-51.

[5] Chidi IL, Rose U, Uche A, "The Role of Religious Education in Improving the Image of Disabled Persons in Nigeria," Journal of Philosophy, Culture and Religion, 2015; 12: 25-36.

[6] Sumartini S and Hadi N, "Pedoman Model Toleransi Kehidupan Beragama, dari pengalaman Sosial Budaya Komunitas Tengger, Desa Ngadas, Kabupaten Malang," Malang: Cakrawala Indonesia, 2010, pp.15-6.

[7] Suseno FM, "Etika Jawa, Sebuah Analisa Falsafi tentang Kebijaksanaan Hidup Jawa," Jakarta: PT Gramedia Pustaka Utama, 2003, pp:38-80

[8] Halim A, "Cultural Capital to Establish Spirit Nationalism Study of Values Local Dayak Communities Border Region in Sub JagoiBabang, BengkayangRegency,West Kalimantan Province," Research on Humanities and Social Sciences, 2015; 5(20): 9-15.

[9] Purnomo M, Binternagel N, Faust $H$, "Transformation of Resource Management in Upland East-Java, Indonesia - From Directive Power to Social and Institutional Interactions," Proceding International Symposium "Sustainable Land Use and Rural Development in Mountainous Regions of Southeast Asia, Hanoi. 21-23 July 2010.

[10] Hefner RW, "Publik Islam and the Problem of Democratization," Sosiology of Religion, 2001; 62(4): 491-514. [13] Stange P,
"Silences in Solonese Dance Production," Journal of Southeast Asian Social Science, 1994; 22:210-29.

[11] Spradley JP, "Metode Etnografi," Yogyakarta: Tiara Wacana, 2010, pp:56-299.

[12] Mils MB and Huberman AM, “Analisis Data Kualitatif,” Jakarta: UI Press, 2002, pp.97-107.

[13] P. Stange, "Silences in Solonese Dance Production," Journal of Southeast Asian Social Science, 1994; 22:210-29.

[14] Mishra N, Mondal D, "Good Governance and Human Rights: A Critical Study With Refrence To Medical Negligence Cases," International Journal of Multidisciplinary Educational Research, 2015; 4: 2(4): 232-46.

[15] Durkheim E, “The Elementary Form of the Religious Life," New York: Free Press, 1992, pp:28-9.

[16] Babalola OO, Danladi JD, Akomolafe JK, "Regional Integration: Challenges and Prospects for Africa," International Journal of African and Asian Studies, 2015; 14: 167-75.

[17] Xiang Z, "Cultural Studies of Tibetan Packaging of Handicraft Products," Atlantis Press. 2015. pp:7-9. 
